\title{
DISPUTATS OM "THE STUDY OF RELIGION IN A NEW KEY"
}

Det Teologiske Fakultetsråd ved Aarhus Universitet antog den 16. juni 2003 en afhandling forfattet af lektor Jeppe Sinding Jensen til forsvar for den filosofiske doktorgrad. Antagelsen skete på baggrund af indstilling fra et bedømmelsesudvalg bestående af professor, dr. phil. Armin W. Geertz (formand), Professor Donald Wiebe, Trinity College, Toronto, og Professor Ingvild Scelid Gilhus, Universitetet i Bergen. Afhandlingen, The Study of Religion in a New Key: Theoretical and Philosophical Soundings in the Comparative and General Study of Religion, er udgivet på Aarhus Universitetsforlag.

Forsvaret fandt sted den 12. december 2003. Armin W. Geertz og Donald Wiebe var udpeget som officielle opponenter, og desuden opponerede ex auditorio Ingvild Scelid Gilhus, adjunkt, ph.d. Jesper Sørensen og professor, dr.theol. Svend Andersen. Nedenfor bringes en udvidet udgave af den officielle opposition ved Armin W. Geertz efterfulgt af et svar fra Jeppe Sinding Jensen.

En problemfri religionsvidenskab:

Kommentarer og spørgsmål til The Study of Religion in a New Key

Armin W. Geertz

Hovedformålet med Jeppe Sinding Jensens disputats The Study of Religion in a New Key er at formulere et videnskabsteoretisk grundlag for den generelle og komparative religionsvidenskab. I forlængelse heraf ønsker han at etablere en rationel, videnskabelig ramme for studiet af religion som emne og som teoretisk objekt (s. 179). Han ønsker at redde religionsvidenskab fra på den ene side induktivismens, tekstpositivismens, historicismens og den logiske empiricismes vraggods, og på den anden side fra de ideologiske fælder, som er knyttet til den religiøse transcendentalisme og de mere vulgære former for postmodernisme og relativisme. Han demonstrerer klart, at religionsvidenskaben som enhver anden videnskab ikke har noget ultimativt grundlag, men han argumenterer lige så overbevisende for, at relativismen samt hævdelsen af en religiøs og/eller etnisk adkomst (privileged access) ikke er noget vellykket alternativ.

Et stort tillykke til Jeppe Sinding Jensen (herefter JSJ) og til hele det brogede fag religionsvidenskab. Denne afhandling viser, at den komparative religionsvidenskab er ved at blive voksen. JSJs diagnose af, hvad religionsvidenskaben fejler, og hvad der skal til for at kurere den, finder jeg ganske overbevisende. Det betyder ikke, at jeg ingen kritik har af bogen - ingen bog er perfekt - men afhandlingens blivende bidrag er en teoretisk referenceramme, inden for hvilken man på konstruktiv vis kan være uenig. Forskningens hidtidige kævl transformeres hermed til en slags disciplineret kakofoni. 


\section{Den frygtsomme religionsforsker}

En interessant sidegevinst ved afhandlingen er, at den ikke udelukkende er skrevet til teori-interesserede, men snarere til den historisk-filologisk, beskrivende del af faget. Der skabes ikke alene en videnskabsteoretisk ramme for den komparative, nomotetiske religionsvidenskab, men også for den partikularistiske, idiografiske religionsvidenskab. Man kan karakterisere afhandlingen som en håndbog for ikke-filosoffer $\mathrm{i}$, hvorledes man praktiserer en teoretisk begrundet, generel og komparativ religionsvidenskab. Som eksempler kan nævnes diskussionen om reduktionisme (s. 134-39) og katalogen over de mest almindelige former for forklaring (s. 225-28). Dermed er ikke sagt, at afhandlingen er uden interesse for filosoffer - tværtimod. Filosofferne trænger til at blive klogere på religion og religionsvidenskabens (og her mener jeg ikke den teologiske religionsfilosofis) potentielle bidrag til filosofiske diskussioner.

JSJ evner at tage tunge, komplekse filosofiske tænkere og argumentationer op til diskussion og formår på en umiddelbar og pædagogisk måde at hjælpe os til at forstå de filosofiske problemers relevans for det religionsvidenskabelige projekt.

I den forbindelse er det JSJs overbevisning, at religionsforskere, især religionshistorikere, er grundlæggende frygtsomme. De er ofre for oprigtige om end forfejlede videnskabsopfattelser. I afhandlingen identificeres og forkastes mange af disse forfejlede opfattelser. Man behøver ikke være enig i kritikken eller løsningsforslagene, men man kan ikke længere bare benægte problemerne eller bortforklare dem ved at gentage fordums tåbeligheder. De forfejlede opfattelser opremses (lidt impressionistisk), som følger:

1. Videnskab er værdifri og ikke-normativ.

2. Videnskab er katalogiseringsarbejde.

3. Videnskab konstitueres (alene) af metoder.

4. Videnskab konstitueres af filologisk lærdom snarere end af teoretisk indsigt.

5. Beskrivelser er umiddelbart indlysende og gyldige (dvs. fri for forskerens teoretiske og normative forudsætninger).

6. Faktuelle beretninger er deskriptive frem for rekonstruktive.

7. Impressionistiske sammenligninger er ligeså tilstrækkelige som analytiske sammenligninger.

8. Religionsvidenskab er ikke-reduktionistisk.

9. Såvel tekstpositivismen (dvs. den opfattelse, at teksten alene indeholder og repræsenterer de begreber og kategorier, som skal indgå i forklaringen og fortolkningen af teksten) som tekstmystikken (dvs. den opfattelse, at teksten bliver en hvirvelstrøm, hvorigennem forskeren drages ind i en unio semantica) er tilstrækkelige til en forståelse af tekstens betydninger.

10. Synlighed er lig med empirisk pålidelighed.

11. Form er lig med indhold.

12. Begreber er lig med virkelighed.

13. Oprindelse er (gennem etymologien) lig med betydningen.

14. Modeller og idealtyper er lig med virkeligheden. 
15. Partikularisme er det modsatte af komparativisme.

16. Religionerne leverer selv de kategorier, man skal bruge til at studere dem med.

17. Definitioner er nytteløse spekulationer.

18. Begrænsede sammenligninger løser de videnskabsteoretiske problemer vedr. generaliseringer.

19. En sand religionsvidenskabelig fortolkning bekræftes af, hvad de troende selv mener.

20. Problemet med essenser hører teologien til.

Alle disse forfejlede opfattelser har mere eller mindre at gøre med videnskabsteori. Men afhandlingen tager også almene filosofiske problemstillinger op som f.eks.:

1. Den videnskabelige diskurs.

2. Forholdet mellem forklaring og fortolkning.

3. Forholdet mellem metafysik og rationalitet.

4. Problemerne med de kulturelle entiteters ontologi.

5. Problemerne med de humanistiske videnskabers epistemologi.

6. Referenceproblemet i sprogfilosofi.

7. Problemerne med relativisme.

8. Teorier om livsverdener.

9. Hermeneutikkens betydning for videnskab.

10. Post-positivismen i humanistisk videnskab.

JSJ deler religionshistorikernes legitime beklagelse over, at teologer, filosoffer og psykologer ikke har megen forstand på fremmede religioner. Omvendt understreger han, at religionshistorikernes fremherskende antiteoretiske holdning medfører den uønskede virkning, at såvel spillereglerne som dagsordenerne overlades til lige netop disse discipliner (s. 152, n. 56).

\section{Religionsvidenskabens aksiomatiske grundlag}

Et sted $\mathrm{i}$ afhandlingen opsummeres det nødvendige aksiomatiske grundlag for religionsvidenskaben (s. 287). Udgangspunktet er, at det er muligt at forstå andre mennesker. Dernæst må religionsvidenskaben på tilstrækkelig vis redegøre for undersøgelsesobjektets (religionens) ontologiske karakter. Denne redegørelse kan kun gøres ordentligt gennem en broget kombination af psykologiske og sociologiske teorier i samklang med semantiske og semiotiske. Desuden må disse teorier forklares i lyset af en sprogfilosofi, som tegner konturerne af 'fakta' og 'teorier' i en given analyse. Idealet om at tage udgangspunkt $\mathrm{i}$ empiriske studier forudsætter bagvedliggende teorier, ellers ville der ikke være nogen adgang til empirisk viden. Derfor er en komparativ analyse af religiøse former umulig uden forudsatte generelle begreber. Det rigtige udgangspunkt for en sådan analyse er hverken religiøse individer eller idealiserede ekstrakter af teologiske konceptioner, men derimod semantisk-semiotiske systemer og klassifikationer samt relationelle forklaringer på de semantisk-semiotiske systemers konstitutive elementer. Det sidste aksiom er, at hermeneutikken ikke er metodologisk valgfri: Alle viden- 
skabelige undersøgelser er hermeneutiske. Der er imidlertid ingen sœrlig hermeneutisk metode, som alene tilhører religionsvidenskaben. Jeg ønsker over for disse aksiomer at rejse spørgsmålet: Er de overbevisende nok eller tilstrækkelige til at imødegå den sprogforbistring (à propos de lokale og nationale terminologier, som omtales i de første kapitler af afhandlingen), som kendetegner den internationale religionsvidenskabelige diskurs?

\section{Den problemfri religionsvidenskab}

JSJs argumentationsstil er hortativ, putativ og præskriptiv, men ikke dogmatisk. Han fastholder, at de forelagte løsningsforslag er forslag. De centrale begreber og problemer formuleres, diskuteres og evalueres i forhold til afhandlingens overordnede argumentation på den ene side og de videnskabsteoretiske debatter på den anden side. Ud fra denne sammenhæng peges der på en mulig udvej. JSJ foregiver heller ikke at løse de myriader af problemer, som filosofferne har skabt, men han udkaster fornuftige (reasonable) alternativer. De problemer, der tages op til diskussion, er vidtforgrenede og viser, at man står over for en lærd forsker. JSJ tager vanskelige og nogle gange dunkle emner op med redelighed, humør, optimisme og en god portion pragmatisk sans.

Trods udgangspunktet $\mathrm{i}$ en teoretisk begrundet, komparativ religionsvidenskab, som orienterer sig i forhold til videnskabsteori, men som desværre også står over for uløselige filosofiske problemer, anvender JSJ det han selv kalder en eklektisk tilgang. Begrundelsen eller undskyldningen om man vil ligger i, at det eklektiske kun er eklektisk på overfladen, idet de i afhandlingen behandlede problemer faktisk er forbundet. Han nævner også, at fordi religion er 'et urent objekt' (forstået som 'mangetydigt') og komplekst stridspunkt, så vil "the means to tackle those ... of course also be complex - if not "impure'” (s. 42). Heri kan jeg kun være enig.

Jeg kalder JSJs tilgang 'the whirlwind approach' eller skypumpetilgangen, forstået på den måde, at man som læser hvirvles ind i en videnskabsteoretisk hvirvelstrøm af problemstillinger, hvis forskningshistorie rummer såvel ægte som uløselige eller overdrevne problemer, uforenelige løsningsforslag og modproduktive løsninger. Ud af dette kaos af problemer, tænkere og løsningsforslag træder JSJ frem som den tilbagevendende kriger med fræset hår og svitsede, rygende klæder, men med et ufravigeligt greb om et noget medtaget sværd. Sværdet hedder rimelighed eller på engelsk 'reasonableness'. Sidstnævnte rummer betydningen 'fornuft', men også 'rimelig fornuft'. Mange af de videnskabsteoretiske problemer skyldes en ubøjelighed og absoluthed, som er aldeles urimelig i en menneskelig verden.

I sine detaljerede diskussioner gør JSJ omhyggeligt rede for andre forskeres teoretiske standpunkter, ligesom han udførligt drøfter, hvorvidt og hvorfor han godtager eller afviser dem. De relevante teoretiske spørgsmål tages op til overvejelse, mange teorier drages ind i teksten, og mange stemmer taler gennem afhandlingens mange sider. Selvom JSJs diskussioner generelt er overbevisende, er det også indlysende, at nogle spørgsmål får en mere overfladisk behandling end andre. En mulig kritik vil her være, at der er taget for mange teoretikere op, og ikke så få alt for kortfattet. 
Nogle af afhandlingens kapitler kommer dybere og dybere ned i problemerne (man kommer hvirvelstrømmens kerne nærmere). Der køres ikke i ring, men snarere i lag. Men nogle gange er visse kapitler og passager langstrakte (f.eks. kapitel 7 og 11) og andre gange gentagende og trættende. Et andet problem er, at desto skarpere den agnostiske og filosofiske linse bliver, jo mere uklar bliver udkanterne med det resultat, at man som læser mister overblikket. Et tredje problem er, at JSJ ofte ekvilibristisk arbejder sig direkte ind i en serie uløselige problemer - ikke problemer han selv har skabt, men problemer, der er udtryk for de pågældende debatters øjeblikkelige status.

JSJs løsningsforslag til disse problemer, sympatiske som de er, rejser imidlertid andre metodologiske problemer. Én løsningsstrategi er, med JSJs egne ord, en "no problem science". Sidstnævnte skal forstås således, at mange af de omtalte filosofiske problemer, som man føres ind i, er uløselige, og det konkluderes, at sådan er tingenes tilstand (c'est la vie), dvs. at religionsvidenskaben deler grundlæggende problemer med andre videnskaber, som de alle er tvunget til at leve med. En anden løsningsstrategi, som anvendes nogle gange, er, at problemerne vurderes som hverken 'relevante', 'konstruktive' eller 'økonomiske' i forhold til afhandlingens valgte referenceramme. En tredje løsningsstrategi er, at blot fordi en påstand eller en procedure er usand eller problematisk, betyder det ikke, at påstandens eller procedurens modsætning er sand eller uproblematisk. En fjerde løsningsstrategi består i en appel til rimelighed, barmhjertighed, redelighed og 'the hermeneutics of benevolent restoration' (s. 73), dvs. en retfærdig, rekonstruktiv hermeneutik. Og JSJ praktiserer denne form for hermeneutik over for langt hovedparten af de tænkere, som han beskæftiger sig med. Der er dog enkelte undtagelser: Postmodernister kan han ikke lide, jf. hans skarpt ironiske kritik side 219-21. Sidstnævnte er heldigvis en undtagelse, men tilhører desværre et af de føromtalte tilbagevendende emner.

Vedrørende appellen til rimelighed: Jeg er normalt enig i JSJs fornuftige overvejelser. Han er en meget fornuftig person, en gang imellem lidt idiosynkratisk ligesom vi andre. Som konsekvens heraf rejses det (måske) urimelige spørgsmål: Hvis fornuft og rimelighed (whose reasonableness) skal være den gældende målestok i forhold til de omtalte vanskelige filosofiske og videnskabsteoretiske problemer? Under forsvaret kunne JSJ ikke se problemet. Jeg havde håbet, at han ville diskutere en passage s. 317-18. Passagen lyder:

\footnotetext{
Rationality ... is no longer a state of affairs resulting from the operations of formal procedures. Rationality is rather to be likened with a set of criteria for 'reasonableness' and the reflective understanding that our standards are human images that can be right or wrong. This is not relativism, it is, on the contrary, as much realism as we can get and we simply have to be reasonable. This may look like 'voodoo epistemology', but it is not-it is just what makes communication at all possible. (s. 317-18).
}

Det vil være rart, hvis han i denne kontekst vil benytte lejligheden til at udfolde dette efter min opfattelse metodologisk set ret centrale standpunkt. 


\section{Religionsvidenskabens problemløsning}

JSJ argumenterer for, at vejen til religionsvidenskabens problemløsning er en kombination af en intern realisme, konceptuel relativisme og semantisk holisme, eller, med andre ord:

... a realist (of sorts) in what concerns our relations to the physical world, an 'anti-realist' in what concerns the relations between language and the world, and a 'symbolic realist' in what concerns the ontology of cultural systems (s. 229).

Semantisk holisme er en form for betydningsrealisme (dvs. den godtager religiøse betydninger som sociale fakta), men den afviser det religiøse sprogs referencialitet $i$ forhold til en objektiv virkelighed (dvs. at 'anti-' skal forstås som 'ikke-referencebar', at symboler ikke antager deres betydning i relation til den ikke-lingvistiske verden). Den symbolske realisme på den anden side finder betydninger i de sociale realiteter, som gøres offentligt tilgængelige i sproget selv.

Dette løsningsforslag rejser et trivielt spørgsmål, men som er af afgørende betydning for mange troende, nemlig hvordan det er muligt videnskabeligt at hævde, at det religiøse sprog ingen relation har til den ikke-lingvistiske verden? Donald Wiebe gjorde en del ud af spørgsmålet under forsvaret. Hans indvendinger var dog ikke teologisk eller religiøst motiverede, men snarere efter mine begreber lidt gammeldags positivistisk motiverede. Det kan være, at JSJ også kan tage dette spørgsmål op her.

Et andet problem med løsningsforslaget er, at der er tale om en slags polyontologi, der, som han selv skriver, sikkert vil være genstand for såvel filosofisk som andre former for kritik. Han argumenterer for tre virkelighedsniveauer (s. 256-58), som Svend Andersen under forsvaret borede lidt i, og som JSJ besvarede fuldt tilstrækkeligt. Det jeg synes skal forklares nærmere, er diskussionen s. 263ff af epistemologi, kultur og semantik. Jeg fandt dette sted i teksten forvirrende, ikke fordi argumenterne er uklare, men fordi jeg synes, at JSJ hele tiden er på kanten af den relativisme, han selv er modstander af. I forlængelse af diskussionen om de to typer af realisme, den stærke eller videnskabelige og den svage eller 'figenblads'-agtige, hævder JSJ, at man må kombinere en moderat realisme med en moderat kulturel relativisme. Jeg undrer mig bare. En årsag til den nutidige metodologiske misere er netop, at folk har svært ved at holde disse ting ude fra hinanden. Det er ligesom at vælge mellem gryden og ilden. JSJs kritik af postmodernistiske påstande taget $\mathrm{i}$ betragtning vil jeg gerne vide, hvad der menes her. Er der tale om inkompatible kulturelle verdener eller hvad? Skal følgende citat forstås således?:

In fact, and this is the subtle irony of the situation, it is only through a realist epistemology that we can uphold a cultural relativist world-making picture without dissolving the substance of a scholarly discourse on religion (s. 271). 


\section{Religioner og arter}

Et andet problem, som måske kunne trænge til en uddybning er formuleret således:

It is, contrary to common public opinion, not the religions of the world that generalize about themselves, present their typicalities and furnish the categories for their interpretation. Epistemology has taught us that the furniture of the world does not present itself to us with its own appropriate labelling. The 'naming of things', as so often pointed out in cosmogonic myths from around the world, is a human feat (s. 166).

Dette ellers udmærkede argument nævnes også andre steder i afhandlingen (s. 23, 64, 131). Men det rejser problemer af to forskellige slags, det ene mere empirisk, det andet mere teoretisk, nemlig: 1) At religionerne ikke generaliserer om sig selv, og at de ikke selv kan bidrage med deres typiske træk (typicalities). Et spørgsmål til JSJ er: Har du nogen sinde talt med et Jehovas Vidne? 2) Argumentet begrundes med et argument om den naturlige verden: "the furniture of the world does not present itself to us with its own appropriate labelling”. Problemet er her: Er religion en 'natural kind' på lige fod med 'stol', 'stjerne' og 'bil'? Citatet harmonerer ikke med en tidligere formulering, som fastslår, at religion ikke er en naturlig ting, men snarere en praktisk eller kulturel ting (s. 143 samt n. 32).

\section{'Og Herren sagde: Lad teksten tale selv!'}

Før jeg blev en oplyst religionshistoriker, sagde JSJ en gang til mig: "Enten er din tekstforståelse forbavsende naiv eller forbavsende dybsindig". Jeg ville ønske, at min tekstforståelse var af sidstnævnte slags, men jeg er unægtelig elev af Halfdan Siiger og Erik Haarh, som jeg holdt meget af, men hvis tekstforståelse jeg i dag ikke deler. Gennem årene har jeg imidlertid ikke kunne slippe den tanke, at uanset de videnskabsteoretisk forkerte ting, vi som religionshistorikere har gjort, har vi dog alligevel formået at producere brugbar, relevant og replicerbar viden. Hvordan har dette været muligt?

Med inspiration fra Paul Ricoeur pointerer JSJ s. 238, at man i en redegørelse for fransk grammatik ikke nødvendigvis skal producere en historisk forklaring eller identificere de kognitive årsager til fransk mentalitet (French minds, s. 238). En fransk grammatik skal forklares i forhold til, hvorledes den er strukturelt opbygget, og hvorledes den fungerer $\mathrm{i}$ forhold til syntaks og pragmatik på sit eget så at sige 'ontologiske' niveau. Denne form for forklaring kalder han 'interne forklaringer', dvs. en forklaring som ikke er afhængig af "reductive reasoning in order to make sense". Endvidere hævder han (s. 239), at religiøse forklaringer er socialkulturelle og semiotisksemantiske, og fordi afhandlingens analyseniveau netop drejer sig om det semantiske "then that entails the possibility of explaining things religious at a non-reductive level". Jeg foreslår, at dette kan være grunden til, at de mange partikularistiske studier faktisk producerer mere eller mindre bevidst videnskabelig viden på grund af deres fremhævelse af "at lade teksterne tale selv" - uanfægtet udsagnets indlysende metafysiske karakter. Denne type analyse forsøger faktisk at relatere tekstens udsagn til dens 
systemiske og historiske kontekst. Kan man derfor i lyset af dette hævde, at tekstempirikere godt kan være gode forskere, selv om de er naive filosoffer?

Lidt i forlængelse af denne diskussion trækker JSJ på Umberto Ecos teori om tekstens intentionalitet (s. 253). Det hævdes, at "this theory firmly supports, in principle, the text-reading practice in the study of religions, independently of believer's intentions $\ldots$ and in fundamental agreement with the theoretical observations made above". Kan denne udtalelse forstås som en bekræftelse på ovennævnte antagelse?

\section{Humor og alvor}

Under forsvaret rejste jeg et par andre omfattende spørgsmål, som jeg ikke skal udfolde her, men som for en god ordens skyld bør nævnes. Det første spørgsmål drejer sig om en manglende religionsdefinition (der er opløb til definitioner på s. 131, 142, 258, 32021, men ingen formel definition). Men det spørgsmål tog Jesper Sørensen op i sin opposition, og da han anmelder bogen i næste nummer af RvT, går jeg ud fra, at spørgsmålet vil blive taget op dér. Det andet spørgsmål, som jeg tog op under oppositionen, gik ud på at få JSJ til at lege lidt med et grid-system à la Mary Douglas (en slags: 'realms of comparability table') i forbindelse med hans vigtige skelnen mellem fire typer universalier, som befinder sig på tre forskellige virkelighedsniveauer (s. 124f). Det lader jeg ligge, fordi jeg siden hen er blevet overbevist om, at et sådant grid-system nok vil være for vanskeligt at applicere. Det sidste spørgsmål, som jeg rejste under forsvaret, var en invitation til JSJ til at samle sine spredte bemærkninger om kognition og kultur (især i kapitel 12) til en sammenhængende argumentation. Men da afhandlingen $i$ bund og grund drejer sig om noget helt andet, er der ingen grund til at tage spørgsmålet op her. Det emne er han i øvrigt godt i gang med at diskutere i andre sammenhænge, ikke mindst i forbindelse med satsningsområdet "Religiøs narrativitet, kognition og kultur" under Afdeling for Religionsvidenskab og det Religionsteoretiske Laboratorium.

Som afslutning på dette debatindlæg vil jeg citere nogle af de mange humoristiske visdomsord, som findes spredt $\mathrm{i}$ afhandlingen:

Science is not constituted by method alone, otherwise astrology or philately would be eminent candidates for recognition as science. (133)

... as humans, we also have that epistemologically remarkable ability to be able to imagine what it is that we cannot do or think. On this issue, religion is our primary witness. (190)

Some anthropologists assert that they shall or will not compare anything, but only record Otherness in all its specificity and in its own terms. This agenda, mostly politically motivated, I would characterize as ventriloquist's or a shaman's methodology. (191)

Og den bedste vittighed $\mathrm{i}$ afhandlingen: 
Personal experience has taught me that a typical department for the study of religion may have a staff combined of, for instance (specialization): Three theologians (Paul's letters, the counter-reformation, lesbian theology), an anthropologist (cargo-cults), a semitic scholar (Aramaic inscriptions), an indologist or two (Upanishads and some pilgrimage shrine), a sociologist (crime and values among urban gangs), two philosophers (Hegel and epistemology), a historian (rural France in the middle ages), a few philologists specializing in, say, Greek, Roman and Hellenistic religions - so it is no wonder that they sometimes fail to express 'collective intentionalities'. Contrariwise, most scholars in a linguistics department are linguists and anthropology departments seem to reproduce almost by cloning. (s. 435, n. 40).

\section{Afsluttende bemærkninger}

JSJs projekt er ambitiøst og vellykket. Afhandlingen afspejler en imponerende fortrolighed med den teoretiske og empiriske litteratur, og JSJ har eftertrykkelig bevist, at han behersker dette meget vanskelige stof. Med denne afhandling er det lykkedes JSJ at bidrage fundamentalt til religionsvidenskabens teoretiske grundlag, at flytte religionsvidenskaben hinsides den traditionelle religionshistories og religionsfænomenologis empiricistiske faldgruber samt at gøre det muligt for religionsvidenskaben at producere en generel, teoretisk forståelse af religion og religioner. Det skal han have tak for.

Armin W. Geertz

Professor, dr.phil.

Afdeling for Religionsvidenskab

Aarhus Universitet

\section{Replik til Armin W. Geertz}

Jeppe Sinding Jensen

Det ville være ganske uforskammet, hvis jeg på nogen måde var utilfreds med Armin W. Geertz' indlæg (herefter AWG), der er en videre bearbejdelse af hans opposition til forsvaret af disputatsen i december 2003. Det er jeg heller ikke. Tværtimod er jeg ganske overvældet over den interesse, som AWG har vist mit projekt og den omhu og loyalitet, hvormed han har behandlet det; først i votum, siden i oppositionen ved forsvaret og nu i sit indlæg. Der har været og er en række meget positive betragtninger og vurderinger; dem kan jeg kun takke for. Der er ganske få punkter, som jeg måske kunne være uenig i, men hvor uenigheden eller forskelle i læsningen måske bunder i, at jeg sandsynligvis har skudt ved siden af eller ikke underbygget argumentet tilstrækkeligt. Men alle de mange helgarderinger kan også indebære en risiko for, at det endnu en gang bliver for gentagende osv. og uden at det synes at eliminere fejlkilder, som nogle af diskussionerne i forbindelse med forsvaret tydede på. 
Vi kan derfor forsøge os med lidt 'disciplineret kakofoni', som AWG meget passende kalder det. Da den kritiske del af AWGs indlæg overvejende består af en række spørgsmål, skal jeg her forsøge at besvare dem på en måde, så hensigten med det skrevne bliver mere tydeligt. Der kan jo ikke herske tvivl om, at i genrer som denne har forfatteren faktisk intentioner, og nogle af dem kan af-dækkes - endog af forfatteren selv. Det skal selvfølgelig også noteres, at intentionerne ofte retter sig mod den forventede ('intenderede') læserskare, og at en diskussion af den samme problemstilling kan tage sig ret forskellig ud, alt efter hvem der læser, og hvem det er skrevet til. Selvfølgelig er forfatterens intentioner også styret af den viden, litteratur, teori osv., som er bragt i cirkulation i et sådant projekt. Forfatterens 'intention' bliver sådan set ikke til meget andet end en bekvem betegnelse for en 'place-holder' for en til tider næsten ustyrlig mængde af diskurser, modeller, teorier, forklaringer, fortolkninger osv., der har forfatteren som kanal og koordinator. I den forstand eksisterer forfatterens intention ikke som et selvstændigt, subjektivt fænomen - det er derimod et netværk af, hvad man kunne kalde 'distribueret videnskabelig kognition', hvor jeg, eller rettere produktet, ved et tilfælde er blevet ét blandt mange knudepunkter. Som i øvrigt nu lever sit eget liv og stort set uden for min kontrol.

Der er en række punkter, hvor en mindre opklaring forhåbentlig kan hjælpe. Omkring 'aksiomet' og aksiomerne spørger AWG til, om de er 'overbevisende nok ...' til at imødegå kritik i forskellige egne af religionsforskningens verden. Mit svar er nok et let bedrøvet, men meget realistisk 'nej', fordi det er min klare erfaring, at risikoen for at blive forstået er som 1:10 i forhold til chancen for at blive misforstået. Kort sagt: der investeres ofte langt mere intellektuel energi i misforståelsens ærinde end i forståelsens. Hvis aksiomerne falder, så falder afhandlingen også - i nogens øjne. Men i min egen forståelse er aksiomerne ikke andet end indlysende. De er jo ikke valgt arbitrært trukket op af en hat eller noget lignende. Aksiomerne er valgt som grundlag, fordi deres historie har vist, at der er 'noget om snakken'. I den forstand er aksiomerne kontingente, men de er ikke vilkårlige. Selvfølgelig er aksiomerne også koblet til meta-teoretiske og filosofiske overvejelser og standpunkter, som må accepteres, hvis aksiomerne skal have gyldighed og kunne fungere som erkendelsesledende.

Et andet problemfelt gælder den nødvendige (som jeg ser det) 'eklekticisme', illustreret f.eks. med begrebet 'impure object'. Dette begreb er ikke nødvendigvis kun 'mangetydigt', som AWG bemærker, men nok snarere 'urent' i den forstand, at det er meget komplekst sammensat - og det er religion om noget. Begrebet stammer fra kemiens verden, hvor 'impure objects' er sammensatte stoffer og det gælder ikke mindst for fabrikerede eller syntetiske stoffer. Religion er sådan set også fabrikeret og syntetiseret - især i forskningens verden, så derfor fører den multi-metodiske pragmatisme hurtigt over i en teoretisk og epistemologisk 'promiskuøsitet'. Det er grunden til, at jeg valgte at diskutere med John Dupré, som viser, at biologien har problemer, der ligner religionsvidenskabens - hvad nok ikke mange religionsforskere ville vente. Det hænger også lidt sammen med bemærkningen om, at der er taget for mange teoretikere op. Her er der kun at henvise til genrens (dvs. disputatsens) krav om, at man skal demonstrere, 
at man er bekendt med, kan indplacere, forholde sig kvalificeret til osv. alt, hvad der måtte være af relevans - oftest defineret ved, hvad andre mener om en given sag. Der er en ganske stor mængde materiale, om hvilket man må sige, at jeg har det med, fordi konventionerne ville, at det skulle med; jeg kunne godt selv leve uden. Men der skal jo også være plads til noget nyt og anderledes, f.eks. Dupré, for ellers ville vi bare køre i ring i den samme gamle religionshistoriske skure, og så kunne vi ikke se, hvad andre fag tumler med. Det har for mig været beroligende at finde ud af, at det ikke kun er os, der hænger på nogle uløselige problemer. Derfor må man så nogle gange se, om dette eller hint problem er f.eks. 'økonomisk' eller overhovedet relevant som problem.

Om jeg kan 'lide' postmodernister, er et mere problematisk spørgsmål. For det første synes jeg ikke, at der er ret mange, som faktisk er det; der er mange, der lader som om og slår om sig med smart snak, der for det meste lander i platituder eller obskurantisme. Mine diskussioner af f.eks. relativisme skulle netop vise, at det ikke er noget, som man behøver at tage særligt alvorligt, forudsat man gør sig bevidst, om man er mere eller mindre relativistisk, 'for så vidt angår' det ene eller det andet. Når man har gjort det, findes problemet ikke længere. I den forstand kan videnskabelige og filosofiske tekster også være en slags 'læsemysterier'. Til 'rimeligheds'-problemet og appellen derom siger AWG:

Som konsekvens heraf rejses det (måske) urimelige spørgsmål: Hvis fornuft og rimelighed ( whose reasonableness) skal være den gældende målestok i forhold til de omtalte vanskelige filosofiske og videnskabsteoretiske problemer? Under forsvaret kunne Jeppe ikke se problemet. Jeg havde håbet på at han vil diskutere en passage på side 317-18.

Når jeg åbenbart ikke kunne se problemet under forsvaret, må jeg se, om jeg kan nu men det kniber faktisk. Der er nemlig ikke tale om, at rationalitet er nogens - forstået på den måde, at rationalitet, som jeg her behandler det, netop er alles. Rationalitet er ikke forskeres, advokaters, lægers, smedes eller midaldrende mænds eller kvinders osv. Der er ikke nogen særlig rationalitet, sådan som jeg udlægger det efter diskussion med Brown og Putnam; det er det nye ved denne opfattelse af rationalitet. Det er muligt, at Maorierne har (haft) nogle meget sære ritualer, sådan umiddelbart set herfra, men i konteksten, og på de givne præmisser, er de fuldt ud lige så rationelle som Københavnske taxa-chauffører (fra A til B med størst mulig indtjening); men præmisserne kan hvile på forskellige epistemiske grundlag og måske manglende ønske om at revidere grundlagsantagelser. Men det er en anden sag - så det handler om epistemologi og ikke om rationalitet.

Som beskrevet her, hvor jeg følger Hilary Putnam, er rationalitet en ikke-reducerbar, såkaldt 'primitiv' forpligtelse på rationalitet som en del af den menneskelige grundkonstitution: f.eks. at kunne følge regler, men også at kunne transcendere dem, hvor der ingen regler gives og evt. ved at lave nye regler. 


\section{Om realismer}

Den semantiske holisme, som jeg bygger min argumentation på, er på sin vis en ganske kompliceret størrelse, når det handler om sandhedskriterierne. Det er en filosofisk diskussion, som jeg har ønsket at gå uden om, fordi den ganske enkelt kunne føre for vidt - og projektet er komplekst nok i forvejen. Den amerikanske filosof Donald Davidson er min hovedinspirationskilde og faktisk den person, der er citeret over flest sider i bogen. Hvis man er meget uenig med Davidson, vil man nok også være uenig med mig. Det kan man sikkert også være, uden at det får fatale konsekvenser for mit projekt, der netop går ud på en finde en mulig vej ud af det teoretiske morads. Jeg mener at have fundet én, men det udelukker ikke andre. I mit tilfælde har Davidsons sene arbejder givet mulighed for en rimelig konsistent teoretiseren. Uden at skulle eller ville fremstille den semantiske holismes program her, er det på sin vis også en forlængelse af både strukturalismen og semiotikken, og i hovedsagen en filosofi om mening, betydning og reference. Termen 'anti-realist' henter jeg fra Michael Dummets sprogfilosofi, og min pointe med at hævde dette synspunkt er, at en religiøs diskurs kan være absolut meningsfuld, selvom den måske i anden sammenhæng lider af massiv referentiel frakobling, hvad angår den del af verden, hvor f.eks. tyngdekraften er en kendsgerning. 'Anti-realist' betyder i den udlægning blot, at det ikke er referencen, der giver et tegn mening, og derfor er der sådan set intet nyt i mit bidrag på dette punkt; for set i en sprogfilosofisk sammenhæng har dette været kendt siden Freges tid. Nu er det ikke ret mange religionsforskere, der kender hverken Frege eller resten af historien, og det er den beklagelige årsag til, at jeg fandt det både nødvendigt og gavnligt at inkludere det pågældende afsnit. Min kobling af de tre 'realismer' skal sikre, 1) at vi kan skelne mellem religiøst og videnskabeligt sprog, for at det hele ikke skal havne i totalt udflydende former for relativisme, 2) at det kan hævdes, at religion er meningsfuld menneskelig aktivitet, som derfor er værd at studere, trods kobling til referencer, der ligger uden for videnskabelig rækkevidde, og 3) at tegnsystemer har en objektiv eksistens, som gør den symbolske verden til en realitet, der kan studeres videnskabeligt på sit eget niveau - uden at det skal 'proppes ind i hovedet' på nogen, som det ellers er blevet så smart at gøre i den i visse sammenhænge herskende individualistiske metodologi og dertil hørende filosofiske mentalisme. I forlængelse af denne diskussion har AWG følgende spørgsmål:

Dette løsningsforslag rejser et trivielt spørgsmål, men som er af afgørende betydning for mange troende, nemlig hvordan er det muligt videnskabeligt at hævde, at det religiøse sprog ingen relation har til den ikke-lingvistiske verden? Donald Wiebe gjorde en del ud af spørgsmålet under forsvaret. Hans indvendinger var dog ikke teologisk eller religiøst motiverede, men snarere efter mine begreber lidt gammeldags positivistisk motiverede (s. 62).

AWG har ganske ret i sin vurdering af Wiebes indlæg, og det skal jeg ikke gøre mere ud af. Hvad 'de troende' måtte synes, kan jeg heller ikke bruge til noget, for 'de' synes så meget - som vi så forsker i, uden at 'de' skal være nogen kontrollerende instans. Men 
jeg må have gjort mig til genstand for en fundamental misforståelse, hvis jeg skulle mene, at 'det religiøse sprog ingen relation har til den ikke-lingvistiske verden'. Det ville da være en idiotisk påstand. Jeg vil hellere vende sagen på hovedet og sige, at det skulle være videnskabeligt muligt at hævde, at det religiøse sprog har relation til den ikke-lingvistiske verden - for selvfølgelig har det det. Religion, religioner, religiøse diskurser, religiøst sprog handler jo netop om alting og derfor også om denne verden, men i koder, som valideres og tildeles autoritet gennem transcendente koblinger. Her kommer den semantiske holisme med en anden pointe, nemlig at det religiøse sprog ikke har nogen anden status end almindeligt sprog - 'det religiøse sprog' er parasitært i forhold til det almindelige sprog. Det har dermed ikke noget epistemisk primat inden for videnskabens rum. Derfor kan divergerende religiøse sprog sagtens have interpretativ varians - det er f.eks. omkring dette punkt, at relativisme-'dæmonen' bør uddrives. Det fører til min 'polyepistemologi' - som selvfølgelig vil blive angrebet af vor tids 'monofysitter' - eliminativisterne og materialisterne, som for min skyld kan hævde, hvad de vil, for det er uden betydning for denne sammenhæng. Som den kloge mand Nelson Goodman vil jeg også mene, at man sagtens kan glæde sig over en verden malet i akvarel og samtidig tage videnskaben alvorligt. Selv om man metaforisk kan tale om 'tunge tanker', så er det virkeligt interessante og for mig nok det mest mirakuløse i dette univers, at vi mennesker er udviklet sådan, at vi kan producere 'ikke-gravitationelle' objekter, nemlig i tankens univers. Selve det faktum, at vi kan det, betragter jeg på en og samme tid som det største mysterium og det mest enkle faktum. Derfor er jeg også nødvendigvis kulturel relativist, for så vidt angår den enkle deskriptive kendsgerning, at kulturer eksisterer ' $i$ en vis forstand', og at de er forskellige ' $i$ en vis forstand'. Men mere er der heller ikke at sige til den sag. Det ligger i klar forlængelse af Hilary Putnams 'interne realisme', som jeg inddrager som mit epistemiske grundlag for det videnskabelige projekts validitet. Såvel Putnam som Goodman repræsenterer en pluralistisk erkendelsesteoretisk linje, der, når den omsættes til human- og socialvidenskabernes områder, tillader, at samme sag kan ses under forskellige beskrivelsesrammer og ud fra flere teorier, der ligesom f.eks. kulturer er mulige betydningskonfigurationer. Denne accept af flerheder kan let opfattes som en form for relativisme, men sådan ser jeg det ikke. Problemet omkring 'inkompatible verdener' bliver hermed til et skinproblem, for selvfølgelig er visse kulturelle fænomener inkompatible, f.eks. wok-mad og smørrebrød, men det er ikke andet end en simpel funktion af forskellighed. Diskurser, ritualer og meget andet, herunder kulturer, kan også være inkompatible i denne ret banale forstand, men det har ikke nogen specielt alvorlige konsekvenser, for de er hverken mere inkompatible eller inkommensurable end, at vi kan sammenligne dem og tale meningsfuldt og rimeligt om deres forskelle og ligheder. Det kan vi, fordi vi har 'meta-sprog', som det hed i den nu lettere arkaiske empiristiske terminologi: vi har sprog til at 'om-tale', teori-sprog. Så hvis mit projekt indeholder en 'moderat kulturel relativisme' er den ikke mere eller andet end en konstatering af et niveau af kulturelle forskelle, og det kan ikke være særlig kontroversielt. Især ikke når jeg samtidig, med den semantiske holisme i baghånden, vil hævde en lang række af kulturelle universalier, 
også hvad angår religion(er). Forhåbentlig klargør dette citatet fra side 271, hvor jeg påpeger, at substansen ville fordampe fra den videnskabelige tale om religion, hvis ikke vi fastholder en realistisk epistemologi. Så ville det nemlig blive Voodoo og Mama Lola, og tale om religion kunne let blive til religiøs tale. Hvad det da også har været i store dele af religionsfænomenologien, som afhandlingen lægger ud med at præsentere.

\section{Om arternes oprindelse}

Til problemet om etikettering af virkelighederne ('Hov! Er han postmodernist....?) er der to spørgsmål. Til det ene kan jeg sige, at jeg har talt med repræsentanter fra Jehovas Vidner, men min faglige baggrund og mistankens hermeneutik forhindrer mig $i$ at acceptere det, de siger, som den hele og fulde historie. Selvfølgelig kan buddhister generalisere om buddhisme, men det sker sjældent på religionsvidenskabeligt grundlag, for når buddhister og Jehovas Vidner - som er to meget forskellige typer af repræsentanter for religiøse traditioner - taler om deres religioner, så taler de om dem i disse traditioners egne kategorier. Det er det, mange kalder 'emic' med en forkert anvendelse af begrebet. 'En 'emic' beskrivelse er f.eks. lingvistens beskrivelse af et bestemt sprog, men vel at mærke med anvendelse af lingvistikkens begrebsapparat. Derfor vil jeg tillade mig at overlade det til religionsvidenskaben at bestemme, hvad der er 'typicalities', for det afgøres ved anvendelse af religionsforskningens begrebsapparat.

Emnet 'natural kind' er noget helt specifikt i videnskabsfilosofi og epistemologi. Der er i dag ikke mange 'natural kinds' tilbage, måske lige med undtagelse af kvarker og den slags. Men stole og stjerner og biler er under ingen omstændigheder "natural kinds'. Det forvirrer selvfølgelig, at en række antropologiske og psykologiske kognitionsforskere bruger termen om f.eks. katte og fodbolde - men det er, fordi de er filosofisk ukyndige og aldrig har bekymret sig om at slå begrebet op. Religion er derfor heller ikke nogen 'naturlig ting' - det var den måske engang, dengang da 'sjæl' også var en naturlig og udelelig 'ting'. Det er på den baggrund, at jeg vælger at tale om religioner som 'cultural kinds' for at fastholde både, at de er kulturelle betydningsprodukter, og at de er af en 'slags', for hvis de ikke var af en 'slags', kunne man ikke lave en videnskab om dem, generalisere eller sammenligne. Der er så yderligere den pointe, at artsbestemmelsen, spørgsmålet om hvilken 'slags', foretages af forskningen, som bestemmer sit objekt teoretisk. Det nævner jeg bl.a. med reference til Émile Benvenistes syn på lingvistikkens 'deduktive' vending i midten af det 20. århundrede.

\section{Tekst}

Vore gamle lærere Halfdan Siiger og Erik Haarh var nok 'ærke-tekstpositivister'. Men de var det også med god grund, dels på baggrund af den tids almindelige videnskabelige klima i humaniora og dels på baggrund af de mange eksesser, som religionsforskningen havde været udsat for. Derfor vægten på teksterne, og det er ganske logisk, især når

\footnotetext{
${ }^{1}$ Vedvarende fejlanvendelse af dette begreb gør det nødvendigt for mig at gentage historien ved enhver given lejlighed - som her.
} 
talen falder på og om religiøse traditioner med skriftmateriale. Selvfølgelig findes der mange slags islam, mange muslimer kan ikke læse, enhver har sin egen tolkning osv., men alligevel skader det ikke at kende til noget af det tekstmateriale, som muslimer har et eller andet forhold til. Endnu bedre på originalsprog! Derfor kan 'tekstempirikere' sagtens være gode forskere, selvom de er naive filosoffer. Det er dog ikke nødvendigvis i sig selv kvalificerende at være filosofisk naiv, men hvis man, som nogle af de 'gamle' gjorde, skal bruge det meste af sit liv på at lære sytten orientalske sprog med endnu flere alfabeter, så er det fuld ud forståeligt, at der ikke bliver så meget tid til filosofi. Og det er faktisk min klare opfattelse, at det nytter noget at læse tekster, derfor også introduktionen af den semiotiske og symbolske 'realisme' og henvisningen til Ecos lille teori om tekstens intentionalitet. Efter årtier med 'inscrutability of reference', 'indeterminacy of translation', 'incommensurabillty', 'frameworks' osv. er det ret befriende blot at kunne hævde, at tekster, og dermed også diskurser og teorier, ofte har visse træk og egenskaber, som gør dem resistente over for det værste vås. Et eksempel kan illustrere dette: Når 'evolutionister' og 'kreationister' er uenige om historien, om at mennesket nedstammer fra aberne, og henholdvis mener, at det er en videnskabelig sandhed eller et djævelsk påhit, så er det den samme historie, de er uenige om, nemlig historien: 'mennesket nedstammer fra aberne'. Den kendsgerning, at teksten kan fortolkes på et utal af måder, er jo ikke det samme, som at den er et semantisk vakuum, at den 'ikke betyder noget.' Det hele er så enkelt, at det næsten er zen.

Den forfatter som hævder at 'the text is devoid of meaning' skriver som regel om andres tekster, sjældent om sin egen. Derfor også min frækhed med at sige, at vi kan læse teksterne uafhængigt af 'believers' intentions' - hvad der kan få f.eks. tidens antropologer til at gå op i limningen. Jeg vil foreslå, at vi skal læse teksterne som en slags programmer, eller grammatikker, der jo heller ikke er 'virkeligheder'. Hvis vi på den måde bruger teksterne som kort, vil vi bedre forstå landskabet, når vi er i det. I denne forbindelse kunne det være på sin plads at forsvare et nyt og udvidet religionsvidenskabeligt tekstbegreb. Med 'tekst' mener jeg ikke kun trykte ting på papir og eller fastlagte, uforanderlige budskaber. Tværtimod er der tale om et åbent tekstbegreb, hvor 'tekst' henviser til enhver form for artikulation i og af diskursive formationer; det være sig i tale, handling, institutionelle konstruktioner osv. Klædedragt kan også være tekst, for med begrebet tekst forstår vi alt som kan være betydnings- og konventionsbærende og sådan set alt som kan gøres til genstand for interpretation. Således bliver 'tekst' til manifestation af det, som John Searle kalder 'afledt intentionalitet' (s. 427-31). Og derfor skal mit forslag ikke på nogen måde læses som et forsvar for tekstreifikation! Jeg vil videre foreslå, at vi ser på vores brug af teksterne som bidrag til modelkonstruktion og det er en praksis, som slet ikke opfordrer til en gammeldags tekst-positivisme, men hvor tekstlæsningen giver mening under en helt anden synsvinkel. Om dette er 'forbavsende dybsindigt', ved jeg ikke, men det er i hvert tilfælde ikke totalt naivt, og det 'redder' vores tekstlæsningspraksis mod angreb fra mange, som synes at det er unødigt, ubrugeligt, intetsigende og fejlagtigt - synspunkter som kritikerne i øvrigt oftest har fra tekster ... Den helt afgørende pointe med mit projekt er netop at flytte 
fokus fra den subjektive religiøsitet som bærer af religion og som religionsforskningens grundlag til et niveau som er intersubjektivt, sprogligt og symbolsk-kulturelt, hvor kulturelle og sociale formationer, som f.eks. religion, er diskursivt konstituerede og derfor 'læselige' for interne deltagere såvel som eksterne analytikere. Naturligvis skal artikulationerne også forklares og forstås i deres kontekst og i deres historie - for at begribe udsagnet 'tvillinger er fugle' skal man selvfølgelig vide en masse andet om Nuernes sprog, kosmologi, samfund osv.

\section{Varia}

Omkring fraværet af en egentlig religionsdefinition er det rigtigt at den ikke gives, eksplicit eller i fed skrift. Jeg henviser kort til andre steder (se s. 420, note 15), hvor jeg har givet noget sådant, men har valgt at lade det flyde og være meget bredt: 'The term religion refers to a more or less integrated and achitectural design of mind and meaning, one in which various 'spaces' and functions relate to action and thought.' (s. 420) Generelt er inspirationen helt indlysende den sprogfilosofisk funderede, som Clifford Geertz lancerede i sin tid. Det nærmeste jeg kommer en mere fyldig specifikation som resultatet af en ganske lang række overvejelser er indeholdt i de otte punkter på side 433 med udgangspunkt i en diskussion af det meget omstridte spørgsmål om, hvorvidt religion kan være kausal. Til kommentaren om 'grid'-systemet er der kun at sige, at det må med i en senere udarbejdelse af modelkonstruktions-problemet, som Ingvild Gilhus også var inde på i sine spørgsmål i oppositionen. ${ }^{2}$

Under forsvaret kom flere ind på mit forhold til kognitionsteoretisk religionsforskning. Det synes at være en slags lakmusprøve på, om man er 'moderne' ud fra den idé, at fordi det er blevet lanceret som det sidste nye, så er man nærmest atavistisk, hvis man ikke kritikløst abonnerer på hele molevitten. Det gør jeg ikke, jeg har skrevet flere kritiske ting om sagen, og mere er i trykken. Det er jo heller ikke så nyt længere, det har da været kendt siden begyndelsen af 1990'erne. Her i Århus var vi med på vognen før de fleste andre og jeg mener helt klart, at der er faldet interessante ting af undervejs, f.eks. 'mod-intuitivitet', 'imagistisk' religion, men så stor en revolution mener jeg ikke, det er. Min helt generelle indvending går på, at mange af fortalerne ikke nøjes med at tale om deres eget arbejdes fortrin, men mener, at alt andet nu dermed er overflødigt, hvilket er helt urimeligt, når man ser på det spektrum af emner, metoder og teorier, som de mener man kan beskæftige sig med videnskabeligt. Det skyldes ikke mindst deres opfattelse af videnskabelighed som sådan - meget snæver efterligning af empiricistisk naturvidenskab af noget ældre aftapning. Mere skal jeg ikke sige her. Men, som AWG noterer, så er forholdet mellem kultur og kognition dels noget, som jeg arbejder med $\mathrm{i}$ en anden sammenhæng og dels noget helt andet end disputatsens projekt, som netop er ideen om en semiotisk funderet generel og komparativ religionsvidenskab.

\footnotetext{
${ }^{2}$ Sammen med en gruppe kolleger har jeg til den religionshistoriske verdenskongres i Tokyo 2005 foreslået et panel med titlen 'New Conceptual Modelling in the Study om Religion' hvor jeg vil forelægge og afprøve ideer om kombinationer af modeller på forskellige niveauer (materielt, mentalt og symbolsk) og af forskellige typer (repræsentationelle, operationelle og explanatoriske).
} 
Mange tak for den med humoren. Det er nok, fordi alt det skriveri kræver så megen ensomhed, at man må udvikle lidt hyggelig og kontrolleret 'skizofreni' for at kunne holde det ud. Men selv da kan det blive for indfoldet og indforstået. AWG foreslog efter at votum var behandlet af fakultetet, at det måske var en idé, om jeg skrev en lidt mindre bog om, hvordan den første skulle læses ... Jeg håber, at dette indlæg i det mindste har været oplysende omkring nogle af de punkter, der gav anledning til spørgsmål.

Jeppe Sinding Jensen

Lektor, dr.phil.

Afdeling for Religionsvidenskab

Aarhus Universitet 